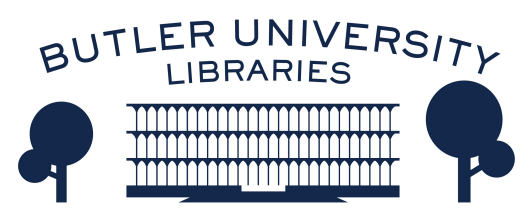

Journal of Hindu-Christian Studies

Volume 15

Article 9

January 2002

\title{
Dialogue at/with the Kumbha Mela
}

M. Darrol Bryant

Follow this and additional works at: https://digitalcommons.butler.edu/jhcs

Part of the Religion Commons

\section{Recommended Citation}

Bryant, M. Darrol (2002) "Dialogue at/with the Kumbha Mela," Journal of Hindu-Christian Studies: Vol. 15, Article 9.

Available at: https://doi.org/10.7825/2164-6279.1276

The Journal of Hindu-Christian Studies is a publication of the Society for Hindu-Christian Studies. The digital version is made available by Digital Commons @ Butler University. For questions about the Journal or the Society, please contact cbauman@butler.edu. For more information about Digital Commons @ Butler University, please contact digitalscholarship@butler.edu. 


\title{
Dialogue at/with the Kumbha Mela
}

\author{
M. Darrol Bryant
}

\section{Renison College University of Waterloo}

HINDUS and Christians have entered into dialogue in a variety of ways. In the last issue of the Bulletin, C. Murray Rogers spoke of his own move to India more than a half century ago and becoming friends with Hindus, Buddhists, and Muslims." In the same issue Shesagiri Rao recounts how "under the influence of Mahatma Gandhi, a number of students...took to the study of the Bible and the Gita." For myself, though I had Raimundo Panikkar as a teacher at Harvard Divinity School in 1966-67, it was meeting Hindus at international interfaith conferences in the 1970s and early 1980s that awakened my interest in dialogue with the Hindu world. Decisive, however, was a sabbatical in India in 1986-87 which allowed me the opportunity to spend time in a number of Hindu communities. Especially important was my time at Jaisingh Ghera in Vrindaban, the ashram of the Goswami family, descendants of one of the six Goswamis that Caitanya had sent to Vrindaban to revive Krishna devotion in the fifteen century. I had met Shrivatsa Goswami earlier, but the time in Vrindaban with my family allowed me to come to know him and his tradition in more depth. It wasn't an academic interest in Hinduism that led me; rather, I was drawn by a desire to understand the faiths that moved and shaped the people I was meeting. Throughout that year, I was able to talk with Hindus, visit their temples, share meals, and read their books. It was a year of human dialogue and exchange. It was from Shrivatsa Goswami that I first learned of this remarkable gathering of millions at the confluence of the Ganga and Yamuna called the Kumbha Mela. And it was Shrivatsa who extended to me an invitation to stay at the Goswami ' camp at Prayag when I attended the Kumbha Mela in 1989 and again in 2001. I saw the Kumbha Mela as an opportunity to continue my own dialogue with Hindus and their faith.

Before I went to the Kumbha Mela in 1989 I was sorely disappointed to find, when searching the libraries, little written in English on the subject. Since 1989, several studies have appeared in English, but I have located only one book on the Kumbha Mela published outside India: Kumbha Mela: The World's Largest Act of Faith, published in 1990. It is a popular account filled with many striking photos from this festival, but weak in its exposition of the faith that brings people from across India to this gathering.

M. Darrol Bryant is Dean and Professor of Religion and Culture at Renison College, University of Waterloo, Ontario, Canada. He has been engaged in the dialogue of religions for twenty-five years and is the authorleditor of over 20 volumes in the study of religion. Those include: "Religion in a New Key" (2nd ed. Kitchener, Ontario, Pandora, 2002), "Religious Conversion, Contemporary Practices \& Controversies" (London: Cassell, 1999) (reviewed in Hindu-Christian Studies Bulletin), "Woven on the Loom of Time: Many Faiths and One Divine Purpose" (New Delhi: Decent/Suryodaya, 1999), Muslim Christian Dialogue: Promise \& Problems (St. Paul, Minnesota: Paragon, 1998). 
II.

The first Kumbha Mela of the new millennium occurred outside Allahabad/Prayag in January-February of 2001. Millions of people had traveled from across India -- by foot, bus, train, tractor, cart and bicycle -- to participate in this remarkable event. They had come from across the world too, in numbers that far exceeded the few people from the West that I had seen in 1989. Sonja Gandhi, leader of the Congress Party, as well as current Prime Minister. Vajpayee attended, giving a political turn to the 2001 event that was missing in 1989.

As one approaches the temporary city laid out on the banks of the rivers, one is caught up in a deluge of human beings streaming into the site. Many carry their supplies for their stay at the Kumbha Mela on their heads as they cross the many pontoon bridges that lead into the city of tents that stretches on both sides of the rivers for nearly as far as one can see. They wear the colorful sarees of India and the marks of the many communities they come from. There are sadhus and householders, some in western clothing, most in the simple dress of the villages. In 2001 , I made my way on foot - the mode appropriate to a pilgrim, I later learned - across the tent city in search of the Goswami compound in the northeast quadrant, grateful that I had been able to get on a train from Delhi to Allahabad. It was early morning, cool but bustling, unlike my arrival in 1989 as the sun set on a camp engulfed in the smoke of cooking fires. Although the Festival normally unfolds over a month, the 2001 event would last 44 days. The numbers swell as the more auspicious bathing days approach. In 1989, there were a reported 15 million in attendance for the big day; in 2001, 20 million were expected. I would stay for a week, while some stay for the whole time in the compounds of their gurus and teachers, and others stay only a day or two.
The sheer size of the tent city encamped by the holy waters of the Ganges and the Yamuna, the endless flow of pilgrims into the camps and down to the water, the blaring loudspeakers with their bhajans, their discourses, their music, their announcements, their ads, all conspire to make the experience overwhelming if not bewildering. Everywhere one turns along the river banks, people are engaged in countless acts of devotion, making their way into and out of the water, making offerings of oil lamps and little woven baskets of flowers, burning sticks of incense in the sand, reciting prayers, and doing puja. In the camps, people gather around their gurus for discourses, or in the presence of Ram, Sita, Krishna and Radha for darshan and worship, or before a stage to see dramas from the Mahabharata or Ramayana being enacted, or to sing praises or read holy texts. Throughout the tent city one also comes upon groups of sadhus, who occupy a special place of honour at the bathing that will take place on the morning of the 24th. It is difficult to know how to name this vast and varied world. It is called the Festival of the Pitcher, but that name initially tells one little.

Some pilgrims told me that the Kumbha Mela had been going on "since time immemorial," and Shrivatsa Goswami said that his family had been coming to the Kumbha Mela since they had come to Vrindaban in the 1500 s. But the origins of this pilgrim event are as uncertain as its age. An informative collection of essays edited by Professor D. P. Dubey from the University of Allahabad is immensely helpful on these issues. Prof. Dubey seeks to unravel the tangled threads surrounding the origins of the Kumbha Mela. Although it is widely believed that the Kumbha Mela goes back to Vedic times, there is no support in the Vedas for such a view and no confirming historical records. However, a Vedic text speaks of the sacred Ganga and the benefits of bathing there. There is also the report of religious festivities at Prayag 
by the Chinese pilgrim Hsuan Tsang in the 6 th century. But whether or not this event was the Kumbha Mela is not known. Another oral tradition credits Sankaracarya (9th century) with organising the Kumbha Mela at Prayag, transforming it from a gathering of a single local group into a "panIndian meeting of ascetics." One sees today that primacy is given to samnyasis and sadhus, especially the Saiva Naga Samnyasis and the Vaisnava Bairagis, on the auspicious bathing days. But the tradition that Dubey favours sees the Kumbha Melas as originating in the 12th century in the "heyday of the Bhakti movement." This tradition is reflected in the catholic character of the contemporary Kumbha Mela, namely, that it draws from all across the Hindu world Hindus of all varieties.

Though the Kumbha Mela is a place of pilgrimage, it is remarkably different from other pilgrimage sites. It is not only a place of pilgrimage, but also a time of pilgrimage, especially in the month of Magha (January), and most especially every twelfth year. The event is sanctioned by a particular solar constellation, which determines the dates on which the Festival takes place. Thus it is both a place and a time that make the 12th-year events Maha (great) Kumbha Melas.

Jack Hebner and David Osborn call the Kumbha Mela "the world's largest act of faith." It is surely the largest - indeed, it dwarfs all analogous religious events. And these numbers have continued to grow throughout this century. However, while the numbers are impressive, they do not clarify the Festival's purposes and intentions. To get at those dimensions of the Kumbha Mela, it is necessary to probe into the stories in the sacred texts of Hinduism and into the minds of the pilgrims who come to the Kumbha Mela.
The sacred texts reveal a wide variety of mythological stories and events that help towards understanding the inner religious purposes of the Kumbha Mela. For example, in the Rig Veda, we are told that those who "bathe at the confluence of the white waters of the Ganga and the black waters of the Yamuma go to the celestial heavens." (Khila-svalayana) And the Garuda Purana (Arca-Kanda 81.2) says that Prayag is "a very holy place conducive to worldly enjoyment and liberation...by taking a bath there, all sins are dispelled." Several ancient texts tell the story of the churning of the ocean of milk and the resulting appearance of a "pitcher" containing a "nectar of immortality." The Bhagavad Purana tells how the appearance of this pitcher of nectar provoked such a clamour on the earth that a messenger of the gods grabbed the pitcher and returned it to the heavens. But in her flight back to the Beyond, some drops of the nectar of immortality fell to the earth. One of the places where the nectar touched the earth was at the confluence of the Ganga and the Yamuna. Some texts add a third, even more powerful river to the two geographical rivers: the Saraswati, an invisible river. Thus the site of this great festival is at the confluence of three rivers, rivers that are at once human and divine. It is noteworthy that neither the Vedas nor the Puranas contain this story in its entirety. It seems to have been stitched together from a variety of sources, some canonical and others independent.

III.

This mythic background allows one to see that for the believer the Kumbha Mela is a place of pilgrimage touched by divine gifts. It is thus a place where human transformation can occur. This expectation became much clearer to me when I had the opportunity to hear Sri Jagadguru Purushottam Goswami, Shrivatsa's father and head of the community, talk about the 
Kumbha Mela. In 1989, he described the Festival as a time for "purification and renewal." Through the centuries, believers have gathered on the banks of these sacred rivers to be renewed by offering their puja to Mother Ganga, listening to the discourses of their teachers, and bathing in the Ganga. For Purushottam, the Festival is a retreat, a time for self-examination and meditation, for reading the sacred writings, for performing acts of devotion and worship to Krishna and Radha. In 2001, Purushottam provided a remarkable discourse on the Kumbha Mela, some of which is reported here.

This place is unique because the nectar of immortality has rained on this place. And devotees gather here to gather that nectar. And what is that nectar? It is devotion to the Lord. Bhakti, or love and devotion to God, is the only proper way, the only proper devotion. And it is only through that devotion -- a devotion wholly without selfishness -- that we gain God, that we gain immortality. The only purpose, then, of the Kumbha Mela is to focus on loving service to God.

I then asked him to explain how that "loving service," the purpose of the Kumbha Mela, is related to bathing in the river Ganga. Sri Purushottam responded,

When the Ganga, the nectar of immortality, was about to descend from the heavens it wondered: if I come to earth, who will revere me? And won't everyone pollute me? But Ganga was reassured: Shiva, the greatest of all devotees, will receive you on his head. And it was Shiva's devotion that persuaded the Ganga to come to earth. And yet the Ganga waited for years to come; she waited for devotees to offer their devotion to the Ganga. The Ganga will cleanse the devotees and their devotion will cleanse the Ganga. Ganga thus came as an act of grace, and their loving service will overcome the pollution that the Ganga will receive.

But Sri Purushottam also made the point that for the mutual cleansing of the rivers and the devotees to occur, it was essential for the heart of the devotee to be rightly focused. In his words,

The Kumbha Mela is the festival of pots (kumbha means a pot). Though the Ganga is so compassionate, it is also important that your heart, the pot, be empty of arrogance and pride. Those who bathe seeking prestige through the holy gift will not receive the holy gift. How could they? Their hearts are already filled with the poison of ambition and so Ganga will not be able to enter..... Those who come in purity and humility will be renewed, for it is humility that makes us open. But arrogance, ambition, and pride are the opposite of loving service and close the heart.

I found this discourse immensely helpful for the light it shed on the inner environment, the faith that the pilgrim brings with her or him. And it is possible to sense the devotion as one watches the pilgrims make their way to the water's edge and enter a river that is more than a river. It is a living symbol of divine grace that flows and renews and purifies those who enter its transforming waters.

\section{IV.}

Festivals celebrate the meeting of divine and human life, or what Mircea Eliade has called "the manifestation of the sacred." Sacred places in widely different parts of the world share either one or all of the characteristic functions of sacred places. They are either 
places of communion between the human and divine, or places of power where human life might be transformed, or places that reflect or embody the sacred order of the divine, or all three of these. Joel Beverton has observed the close connection that exists between sacred places and rituals. This is especially true at the Kumbha Mela where daily activity is filled with ritual activity, beginning with the ritual bathing in the Ganga, the rituals conducted at the rivers as lamps and offering are placed in the sacred waters, the rituals performed in the camps before the enshrined deities, ritual prayers and meditation. Rituals are not only outward gestures and actions but also interior acts and movements of the mind and spirit.

All of these dimensions of the Kumbha Mela are telescoped into events at the Sangam, the place where rivers converge, on the most auspicious day of the Mela. In 2001, the day was January 24th. This was the day when the 20 million gather. A dozen of us in the Goswami compound rose at 2:30 a.m. to make our way to the Sangam, as we wanted to be there for sunrise. Within minutes of leaving the compound, we were in a crowd of wall-to-wall people making its way to the Sangam. It was not an easy trip. The police had closed many of the pontoon bridges accessing the Sangam, so we had to turn back more than once. We finally found ourselves in a tight group moving down a fenced lane towards a bridge of the Sangam. Suddenly I wasn't really walking but being carried along, which was rather frightening. Just then I was pulled out of the line by police shouting "No press, no camera." The rest of our group was swept along, and I watched them disappear as I tried to assure the police that I wasn't "press." After ten minutes, I was allowed to continue. When I arrived at the cold and windswept Sangam, I was surprised to find it more open than in 1989. Police on horseback and on foot were periodically chasing pilgrims away from the centre of the site where the sadhus would come for the first morning dips.
What I began to grasp is what scholars of religion call the "places of power" function of sacred spaces: that is, the conviction among the pilgrims that in these places, "human life might be transformed." Clearly, that was part of the conviction as pilgrims entered the flowing waters of Mother Ganga. Here is my journal entry from February 6, 1989, the Kumbha Mela's most auspicious day. The description also fits my experience of January 24, 2001, though on the more recent day, a cold wind ripped across the site.

Off in the east, the bright ball of the sun inched up the horizon and a roar went up from the crowd: the human world rose up to greet the sun that spreads its crimson rays on this new day. As the sun rose, one could feel the mounting energies. A rush of joy seemed to ripple through the surging crowds. And the sunrise was beautiful: that ball of flaming red rose through the dust and haze like a jewel to refract its light on all. It revealed a humanity that spread as far as I could see along the banks of the rivers and beyond. And, for a moment, the moving waters and the $\mathrm{ebb}$ and flow of the humanity gathered there seemed to dance with one another in perfect harmony as the sun rose over it all.

In 2001, there was a greater attempt by police to manage access to the Sangam than in 1989. We were pushed behind fences as the naked sadhus, the first into the waters at sunrise, came dancing down to the waters.

In both 1989 and 2001, I found myself continually trying to discern the meaning of what I was witnessing. How could I "see" what was happening here? Religious festivals have social, archetypal, and cosmic dimensions that are all combined in remarkably compressed gestures and actions or elaborately dramatized in extended -performative acts -- and all this is certainly 
true of the Kumbha Mela. The questions I had exceeded my answers, but I found myself drawn again and again to the rivers, since it was obviously the rivers that constituted the heart of this sacred place. In India and in Hindu culture, rivers have often been regarded in more than human terms. Rivers bespeak another language, one that is articulated in the myths and legends of Indian life. My journal records some of these thoughts:

It goes on as it has for centuries. I found myself wondering if I was watching an eternal drama, one that would continue as long as humanity remains aware of its need for renewal, for purification, for the revival of the spirit. I wondered as I watched again as the streaming waters of the Ganga met the streaming masses of humanity in the wonderful dance where outer meets inner and becomes a living symbol of something more. 1989:

On my last day at the Kumbha Mela in

I made my way to the river for my final farewells. I felt I wanted to be at the river one last time, to see once again the cycle of pilgrims coming to and from the river, performing their acts of worship, continuing the rhythms that mark this extraordinary event. I can see that Mother Ganga is more than just another river. It is the living presence of the mystery of life's origins and continuities as it ceaselessly flows towards its destiny. It is moving to watch the reverence with which it is approached, entered, and acknowledged through timehonoured rituals. The river is, as it were, an endlessly flowing symbol of grace that renews as it cleanses, that transforms as it receives. For the pilgrim, it seems to have a power, presence, and a persona that is difficult for me to grasp, though I can glimpse it in their acts of devotion. And I find it very moving. There is even a moment when I feel caught up in the archetypal drama ...

At the heart of this festival are the waters of the Ganga, Yamuna and Saraswati -- waters that, in the words of the Bhavisyottara Purana, are "the source of all things and all existence." Eliade writes eloquently of the sacred meaning of water:

In water everything is "dissolved," every "form" is broken up, everything that has happened ceases to exist; nothing that was before remains after immersion in water.... Immersion is the equivalent, at the human level, of death, and at the cosmic level, of the cataclysm which periodically dissolves the world....Breaking all forms, doing away with all the past, water possesses this power of purifying, of regenerating, of giving new birth; for what is immersed in it "dies", and, rising again from the water, is like a child without any sin or any past, able to...begin a new and real life."

It is the transforming power and presence of these sacred waters that make the Festival of the Pitcher a remarkable festival, a remarkable sacred place, and a remarkable place of pilgrimage. It is a place where the rivers flow on and on, reflecting the light of the sun's rising and setting, and carrying with them the offerings of devoted hearts -flowers and oil-lit lamps -- as they silently continue their endless journey. 
V.

In the dialogue of persons of different faiths, it is essential for people to disclose their own faith. And perhaps in no other event in the Hindu world is the faith of Hindus so remarkably unveiled as in the Kumbha Mela. My task as a Christian is to try to understand that faith. I was welcomed to their Festival, not only by the Goswami family but by everyone I met there.
Through my participation in the Kumbha Mela, I was able to draw closer to the Hindu pilgrims whose inner world of belief and gesture was not mine. I have come away deeply grateful for their openness to my presence and impressed by the depth of their devotion. I came to see more deeply what scholars of sacred pilgrimage places have noted, namely, that these are (1) places of communication, (2) places of power, and (3) places that embody. 